\title{
Discrimination of soybean seed lots by multivariate exploratory techniques ${ }^{1}$
}

\author{
Rafael Marani Barbosa ${ }^{2 *}$, Bruno Guilherme Torres Licursi Vieira ${ }^{2}$, \\ Antônio Sérgio Ferraudo 3 , José Eduardo Corá4, Roberval Daiton Vieira ${ }^{2}$
}

\begin{abstract}
Physiological potential characterization of seed lots is usually performed by germination and vigor tests; however, the choice of a single test does not reflect such potential, once each test assesses seeds of differentiated mode. Multivariate techniques allow understanding structural dependence contained in each variable, as well as characterize groups of seed lots according to specific standards. The study aimed at evaluating variability among soybean seed lots and discriminate these lots by multivariate exploratory techniques as function of seed vigor. Experiment was performed with 20 soybean seed lots (10 lots cv. BRS Valiosa RR and 10 lots cv. M-SOY 7908 RR). Seed physiological potential was assessed by testing for: germination (standard, and under different water availability); vigor (accelerated aging and electrical conductivity); and field seedling emergence. Cluster analysis of seed lots, as well as Principal Component Analysis was performed using data obtained on all tests. Multivariate techniques allowed stratifying seed lots into two distinct groups. Principal Component Analysis showed that values obtained for variables: field seedling emergence, accelerated aging, and germination under different water availability were linked to BRS Valiosa RR; while to variables germination and electrical conductivity, were linked to M-SOY 7908 RR.
\end{abstract}

Index terms: Glycine max (L.) Merr., vigor, Cluster Analysis, Principal Component Analysis (PCA)

\section{Discriminação de lotes de sementes de soja por meio de técnicas exploratórias multivariadas}

\begin{abstract}
RESUMO - A caracterização do potencial fisiológico de lotes de sementes geralmente é feita por meio dos testes de germinação e vigor; entretanto, a escolha de um único teste não reflete este potencial, pois cada teste avalia as sementes de um modo diferenciado. Técnicas multivariadas permitem compreender a dependência estrutural, contida nas variáveis, bem como caracterizar grupos de lotes de sementes segundo padrões específicos. O objetivo deste trabalho foi explorar a variabilidade entre lotes de sementes de soja e discriminar estes lotes, em função do potencial fisiológico das sementes, por meio de técnicas exploratórias multivariadas. O experimento foi realizado com 20 lotes de sementes de soja (10 lotes cv. BRS Valiosa RR e 10 lotes cv. M-SOY 7908 RR). O potencial fisiológico das sementes foi avaliado pelos testes de: germinação (padrão, e sob diferentes níveis de disponibilidade hídrica); vigor (envelhecimento acelerado, condutividade elétrica) e emergência de plântulas no campo. Utilizando os dados obtidos nesses testes foi feita a análise de agrupamento dos lotes de sementes, bem como de seus principais componentes. As técnicas multivariadas permitiram a estratificação dos lotes de sementes em dois grupos distintos. A Análise de Componentes Principais mostrou que as variáveis: emergência das plântulas no campo; envelhecimento acelerado; e germinação sob diferentes níveis de disponibilidade hídrica estão mais associadas ao cv. BRS Valiosa RR, enquanto que para as variáveis germinação e condutividade elétrica, associaram-se ao cv. M-SOY 7908 RR.
\end{abstract}

Termos para indexação: Glycine max (L.) Merr., vigor, análise de agrupamento, Análise de Componentes Principais (PCA).

\section{Introduction}

The use of high quality seeds is an essential component on the establishment of any farming system type; and high seed physiological quality is the most important component

${ }^{1}$ Submitted on 10/09/2012. Accepted for publication on 05/12/2013.

${ }^{2}$ Departamento de Produção Vegetal, UNESP, 14884-900 - Jaboticabal, SP, Brasil.

${ }^{3}$ Departamento de Ciências Exatas, UNESP, 14884-900 - Jaboticabal, SP, Brasil. to ensure an appropriate plant population in the field, and consequently allow for the expression of maximum productive potential of a given crop under a wide range of different environmental conditions.

Currently, the low quality of soybean seeds is no longer
${ }^{4}$ Departamento de Solos e Adubos, UNESP, 14884-900 - Jaboticabal, SP, Brasil.
*Corresponding author <rmarani@gmail.com> 
a limiting factor for the establishment of an adequate plant stand in the field. This is due to factors such as: high genetic potential of cultivars currently marketed; supervision of seed production fields by competent bodies, associated to quality control programs; and commitment of seed producers on ensuring their product is competitive on the market. Thereby, the use of high physiological quality seeds becomes a common practice among soybean producers.

In extensive cropping, the main limiting factor to soybean production is the water availability; once water is essential to seed germination process. When soil moisture content is suitable, the seed germination process and plant emergence occur more quickly and evenly. In function of pre-determined periods for crop installation, soybean seeding may be performed in soils that do not have suitable moisture. However, water deficiency may impair the adequate establishment of plant stand in the field, and consequently lowering production. Moreover, seeds may be subject to infection by microorganisms or to attack by soil insects; what exacerbates the problem.

Front of a great amount of different seed lots, the choice of seeds for sowing cannot always be done by observing only the performance potential assessed solely by germination test or by a single vigor test. A more comprehensive analysis of these seeds might be useful and necessary; since in the choice of a seed lot it should be considered more than one single test available to assess potential performance of the seeds of each seed lot.

When seeds are subjected to different situations, they might show variable reactions, which are specific to each assessment test (Vieira, 1994); and application of the Multivariate Analysis allows discriminating the seed lots having common characteristics, and decide whether these seeds will be used for consumption or sowing.

Multivariate techniques are often associated to the problem of how to reduce the original space to minimum dimension numbers needed to description of relevant information contained in the original observations. Different types of Multivariate Analysis (PCA, Factor Analysis, Discriminant Analysis, Cluster Analysis, among others) utilize appropriate models to solution and interpretation of the original variables to obtain specific conclusions (Manly, 2008).

Multivariate technique of Cluster Analysis is used to explore similarities among individuals, among variables (Landim, 2003), or among seed lots. Results of Cluster Analysis are arranged hierarchically, and are generally summarized in a structure called dendrogram (Johnson and Wicherns, 1998). The use of Cluster Analysis is especially useful in exploratory search, in which a priori is held the collection of data not belonging to distinct groups (Alves, 1999).
Principal component analysis is intended to derive a small number of linear combinations (principal components) of a set of variables that retain many of the existing information in the original variables. Thus, this analysis may also be seen as an attempt of evidencing the approximate linear dependences existing between variables. Often a small number of principal components may be used to replace the original variables, to draw graphical representations, regression analysis, cluster analysis, factor analysis, among others (Conagin et al., 2006).

The objective of this study was to explore the variability and discriminate soybean seed lots, in function of seed physiological potential by exploratory multivariate techniques.

\section{Material and Methods}

Soybean seeds were obtained at Farmers Cooperative of the Orlândia Region. For the tests, 10 soybean seed lots of cv. BRS Valiosa RR, and 10 of cv. M-SOY 7908 RR were used. In the laboratory, seeds of each lot were removed from their original packaging, and immediately homogenized, sampled, and stored into multiwall papers bags. Subsequently, seeds of each sample were subjected to the following tests:

Moisture Content: was assessed by the oven method, at $105 \pm 3{ }^{\circ} \mathrm{C}$ for $24 \mathrm{~h}$ (Brasil, 2009). Two replications of approximately $20 \mathrm{~g}$ of seeds were used for each seed lot. Results were expressed as percentage (wet basis).

Germination: was carried out with four replications of 50 seeds, to each treatment. The seeds were evenly distributed upon two sheets of paper moistened with distilled water at a ratio of 2.5 times the dry substrate mass, covered with another sheet. The rolls were placed into a germinator at $25{ }^{\circ} \mathrm{C}$. Percent germination was assessed on the fourth and the eighth day after test start (Brasil, 2009). Results were expressed as percentage of normal emerged seedlings.

Accelerated aging: this test was conducted following methodology described by McDonald and Phaneendranath (1978), into $11 \times 11 \times 3.5 \mathrm{~cm}$ plastic germination boxes used as individual compartments (mini-chambers), to which were added screens of stainless steel fixed to the upper edge, and $40 \mathrm{~mL}$ of deionized water in the bottom. Seeds previously treated with carbendazim + thiram were then distributed evenly in a single layer on the screen surface. Then the boxes were capped, and kept into a germination chamber, adjusted to $42{ }^{\circ} \mathrm{C}$, for $48 \mathrm{~h}$. After this period the seeds were subjected to standard germination test. Test was performed with four replications of 50 seeds each, and assessment was performed on the fifth day after test start. Seed moisture content was determined after the accelerated aging.

Electrical conductivity: was carried out using four 
replications of 50 seeds each, which were weighed on an analytical balance with $0.01 \mathrm{~g}$ precision. The seeds were immersed into $75 \mathrm{~mL}$ deionized water and kept at $25{ }^{\circ} \mathrm{C}$ into an incubator chamber, for $24 \mathrm{~h}$, to allow leaching process. After this period, electrical conductivity reading was measured in the solution with aid of a digital conductivimeter. The results were expressed in $\mu \mathrm{S} . \mathrm{cm}^{-1} \cdot \mathrm{g}^{-1}$ seed (Marcos-Filho and Vieira, 2009).

Field seedling emergence: the test was performed in an experimental area and conducted with four replications of 50 seeds, to each seed lot. Seeds were previously treated with thiram + carbendazim, and manually distributed into furrows $1.5 \mathrm{~m}$ long, with $25 \mathrm{~cm}$ spacing and 2 to $3 \mathrm{~cm}$ deep. Assessment of seedlings emerged was performed on the fourteenth day after sowing (Nakagawa, 1999).

Germination under different water availability levels: this test was conducted with four replications of 50 seeds each, to each treatment. Seeds were sown into rectangular plastic trays with dimensions of $28.5 \times 18.5 \times 10 \mathrm{~cm}$ tall containing a soil composed by the mixture of $62 \%$ sand, $5 \%$ silt, and $33 \%$ clay. To control water available the most important feature to be considered is the soil porosity when the effect of different levels of water availability needs to be assessed. Porosity is related both to soil density and density of particles, and was computed by following equation:

$$
P t=(1-s d / d p) \times 100
$$

$P t$ is total porosity; $s d$ is soil density; and $d p$ is density of particle. According to level that the substrate reaches inside the box, empty box was filled with water to the mark, thereby obtaining the volume occupied by the substrate; soon after, the volume of water was measured with a volumetric flask, expressed in liters. The mass was obtained by weighing with balance of precision $0.1 \mathrm{~g}$. Soil density was determined by the volume $\times$ mass $^{-1}$ ratio, and the results expressed in g. $\mathrm{L}^{-1}$. The density of particle was determined by the method of volumetric flask (Embrapa, 1997).

After determining the amount of soil pores contained in the trays, the different levels of water availability, which were constituted by $20,40,60$ and $80 \%$ of the total pores filled with water, and corresponding to water potential levels of: $-1.0,-0.6$, -0.4 and $-0.02 \mathrm{MPa}$ were established. Considering these values as well as the evaporatranspiration effects daily monitoring were conducted by weighing the trays, for these previously established values were kept constant throughout all the study.

Data were tested, firstly, for normality (Shapiro-Wilk test) and homoscedasticity (Cochran test) and was subjected to ANOVA in a completely randomized design. The means were compared by Tukey test, at $5 \%$ probability separately for each cultivar, to check the efficiency of the procedure of water stress.

In function of factors as: number of variables; need of improving comprehension of factors influencing seed physiological potential; and improving exactness of discrimination between seed lots, the exploratory techniques of multivariate statistics were applied through the Cluster Analysis and the Principal Component Analysis to discriminate the seed lots with better physiological quality, and to characterize the variables responsible by the discrimination.

Multivariate analyzes were only performed after standardization of variables in which each one was with mean 0 and variance 1 . Subsequently, using the data of all batches was processed hierarchical cluster analysis (Sneath and Sokal, 1973) considering as a measure of similarity between pairs of lots the Euclidean distance and the UPGMA (Unweighted Pair Group Method with Arithmetic Average) as the connection mode between the groups.

Principal component analysis allows to condense as much of the original information contained in $\mathrm{p}$ variables ( $p=7$, this study) in two orthogonal latent variables called principal components, which are linear combinations of the original variables created with the two largest eigenvalues of covariance matrix (Hair et al., 2005). Therefore, the initial set of seven variables passed to be characterized by two new latent variables, which enabled their location in two-dimensional figures (ordering of accesses of the principal components). The adequacy of this analysis is verified by the amount of the total information of the original variables retained by the principal components showing eigenvalues greater than unity (Kaiser, 1958). Eigenvalues lower than the unity does not preserve the relevant information.

All statistical analyzes were processed using the STATISTICA version 7.0 (Statsoft, 2004).

\section{Results and Discussion}

Mean of results obtained for the different variables studied are presented on Table 1. That the means obtained for seed moisture content before accelerated aging test (BAA) were different among distinct seed lots assessed, ranging from $11.6 \%(\mathrm{~L} 8)$ and $12.6 \%(\mathrm{~L} 3)$ to $\mathrm{cv}$. BRS Valiosa RR; and between $11.1 \%$ (L4) and $12.8 \%$ (L7) to cv. M-SOY 7908 RR (Table 1). However, according to small variations on seed moisture content do not interfere on results of vigor tests; although uniformity of seed moisture percent is essential for obtaining consistent results (Barbosa et al., 2012). The same has occurred with seeds assessed after the accelerated aging, since it was verified that the seed moisture content variation was also similar on both cultivars assessed. Percentage values obtained for cv. BRS Valiosa RR have ranged between $28.0 \%$ (L3) and 
$29.4 \%$ (L2), and between $27.6 \%$ (L3) and $29.7 \%$ (L10) to cv. M SOY 7908 RR (Table 1); however, not exceeding the limit of maximum variation tolerated, which according to Marcos-Filho (2005) is three to four percentage points.

Table 1. Means obtained by the tests of: moisture content (before and after accelerated aging test); germination; accelerated aging; electrical conductivity; seedling emergence in field; and seed germination under different water potential levels, in seeds of 10 different seed lots of two soybean cultivars.

\begin{tabular}{|c|c|c|c|c|c|c|c|c|c|}
\hline Seed lot & BAA & AAA & G & AA & $\mathrm{EC}$ & SEF & $\begin{array}{c}\text { GWP } \\
-0.6 \mathrm{MPa}\end{array}$ & $\begin{array}{c}\text { GWP } \\
-0.4 \mathrm{MPa}\end{array}$ & $\begin{array}{c}\text { GWP } \\
-0.02 \mathrm{MPa}\end{array}$ \\
\hline & \multicolumn{4}{|c|}{ 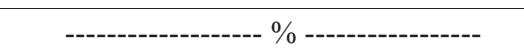 } & $\mu \mathrm{S} . \mathrm{cm}^{-1} \cdot \mathrm{g}^{-1}$ & \multicolumn{4}{|c|}{ 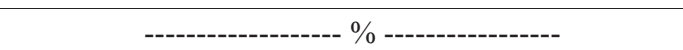 } \\
\hline L1 & 12.3 & 28.6 & $95 a^{*}$ & $85 \mathrm{a}$ & $68 \mathrm{a}$ & $86 \mathrm{a}$ & $90 \mathrm{a}$ & $87 \mathrm{ab}$ & $69 \mathrm{a}$ \\
\hline L2 & 12.2 & 29.4 & $94 \mathrm{a}$ & $88 \mathrm{a}$ & $70 \mathrm{a}$ & $86 \mathrm{a}$ & $91 \mathrm{a}$ & $88 \mathrm{ab}$ & $63 \mathrm{abc}$ \\
\hline L3 & 12.6 & 28.0 & $94 \mathrm{a}$ & $87 \mathrm{a}$ & $70 \mathrm{a}$ & $83 \mathrm{a}$ & $93 \mathrm{a}$ & $84 \mathrm{~b}$ & $61 \mathrm{abc}$ \\
\hline L5 & 12.0 & 28.6 & $92 \mathrm{a}$ & $90 \mathrm{a}$ & $70 \mathrm{a}$ & $87 \mathrm{a}$ & $87 \mathrm{a}$ & $87 \mathrm{ab}$ & $65 \mathrm{ab}$ \\
\hline L6 & 12.2 & 28.8 & $93 \mathrm{a}$ & $91 \mathrm{a}$ & $66 \mathrm{a}$ & $84 a$ & $88 \mathrm{a}$ & $94 \mathrm{a}$ & $57 \mathrm{bcd}$ \\
\hline L7 & 12.1 & 28.7 & $94 \mathrm{a}$ & $81 \mathrm{a}$ & $67 \mathrm{a}$ & $86 a$ & $90 \mathrm{a}$ & $96 \mathrm{a}$ & $58 \mathrm{bcd}$ \\
\hline L8 & 11.6 & 28.8 & $93 \mathrm{a}$ & $84 \mathrm{a}$ & $72 \mathrm{a}$ & $83 \mathrm{a}$ & $90 \mathrm{a}$ & $95 \mathrm{a}$ & $58 \mathrm{bcd}$ \\
\hline L9 & 11.8 & 29.2 & $95 \mathrm{a}$ & $87 \mathrm{a}$ & $69 \mathrm{a}$ & $82 \mathrm{a}$ & $91 \mathrm{a}$ & $95 \mathrm{a}$ & $50 \mathrm{~d}$ \\
\hline L1 & 12.0 & 28.8 & $96 a^{*}$ & $75 \mathrm{a}$ & $90 \mathrm{a}$ & $81 \mathrm{a}$ & $86 a b$ & $93 \mathrm{a}$ & $46 \mathrm{~cd}$ \\
\hline $\mathrm{L} 2$ & 12.0 & 28.7 & $95 \mathrm{a}$ & $79 a$ & $77 \mathrm{a}$ & $83 a$ & $96 \mathrm{a}$ & $92 \mathrm{a}$ & $47 \mathrm{~cd}$ \\
\hline L3 & 11.9 & 27.6 & $97 \mathrm{a}$ & $79 a$ & $91 \mathrm{a}$ & $83 a$ & $89 a b$ & $85 \mathrm{a}$ & $55 \mathrm{bcd}$ \\
\hline L4 & 11.1 & 27.8 & $97 \mathrm{a}$ & $72 \mathrm{a}$ & $86 \mathrm{a}$ & $81 \mathrm{a}$ & $78 \mathrm{~b}$ & $77 \mathrm{a}$ & $42 \mathrm{~d}$ \\
\hline L5 & 11.7 & 28.3 & $97 \mathrm{a}$ & $72 \mathrm{a}$ & $87 \mathrm{a}$ & $78 \mathrm{a}$ & $86 a b$ & $85 \mathrm{a}$ & $60 \mathrm{abc}$ \\
\hline L6 & 12.5 & 29.1 & $97 \mathrm{a}$ & $78 \mathrm{a}$ & $77 \mathrm{a}$ & $84 \mathrm{a}$ & $93 \mathrm{ab}$ & $87 \mathrm{a}$ & $68 \mathrm{ab}$ \\
\hline L7 & 12.8 & 27.8 & $96 \mathrm{a}$ & $81 \mathrm{a}$ & $85 \mathrm{a}$ & $83 a$ & $96 \mathrm{a}$ & $92 \mathrm{a}$ & $44 \mathrm{~cd}$ \\
\hline L8 & 11.6 & 27.8 & $94 \mathrm{a}$ & $75 \mathrm{a}$ & $84 \mathrm{a}$ & $79 \mathrm{a}$ & $93 \mathrm{ab}$ & $93 \mathrm{a}$ & $75 \mathrm{a}$ \\
\hline L9 & 11.5 & 28.9 & $94 \mathrm{a}$ & $78 \mathrm{a}$ & $94 \mathrm{a}$ & $83 \mathrm{a}$ & $91 \mathrm{ab}$ & $87 \mathrm{a}$ & $59 \mathrm{abcd}$ \\
\hline L10 & 12.1 & 29.7 & $95 \mathrm{a}$ & $79 \mathrm{a}$ & $99 \mathrm{a}$ & $82 \mathrm{a}$ & $93 \mathrm{ab}$ & $87 \mathrm{a}$ & $44 \mathrm{~cd}$ \\
\hline
\end{tabular}

*Means followed by the same letter in columns do not statistically differ between each other by Tukey test, at $5 \%$ probability; BAA $=$ before accelerated aging test; $\mathrm{AAA}=$ after accelerated aging test; $\mathrm{G}=$ germination; $\mathrm{AA}=$ accelerated aging test; $\mathrm{EC}=$ electrical conductivity test; $\mathrm{SEF}=$ seedling emergence in field; $\mathrm{GWP}=$ germination under water potential; $\mathrm{CV}=$ coefficient of variation.

The lots of soybean seeds presented similar physiological performance, because no difference was detected between all lots for both the cultivars, except for the variable germination conducted under the potential of -0.4 and -0.02 MPa (Table 1). The germination was above the established for commercialization of soybean in Brazil, namely, $80 \%$. The germination test, conducted under favorable conditions (water availability, temperature and oxigen) can overestimate the performance potential and do not indicate the actual state of deterioration of the seeds (Marcos-Filho, 2005).

Both vigor tests used (AA and EC), as well as the test of seedling emergence in field (SEF) were also unable on detecting differences in the physiological seed quality (Table 1). Thereby, all seed lots assessed for both cultivars were classified as high vigor; thus corroborating the efficiency of the current production of soybean seeds with high quality in Brazil.

The germination of soybean seeds conducted with potential of -1.0 MPa was not effective in highlighting lots because not allowed seedling development. In this potential the water availability was not suitable for the seed to complete the process of soaking. As consequence of this water deficiency the process of germination was interrupted, and besides seeds were infected by soil microorganisms mainly by fungi from Aspergillus and Penicillium genera. Therefore, results obtained in this test were not shown and nor included in the procedures of the cluster and principal components analysis. 
The results of germination conducted under the potential of -0.6 MPa highlighted the lot L3 BRS Valiosa RR and the potential of $-0.4 \mathrm{MPa}$, L4 'M-SOY 7908 RR' with low vigor. These results are not in agreement with the mere comparison to the other tests, which detected no differences in performance between the lots. Additionally, the test was not able to detect this same difference pointed out by the potentials of -0.6 and -0.4 MPa. This occurs because we worked with lots that had high potential performance, so some factor uncontrolled can mask these results, sometimes elevating the results and sometimes underestimating them.

However, when seeds were germinated under the $-0.02 \mathrm{MPa}$ water potential the mean values obtained for germination have varied significantly among nearly all seed lots of both cultivars assessed (Table 1). Oxygen deficiency in some cases, may cause seed decay and impair the germination process. Moreover, seed decay may also delay seedling development and provide favorable environmental conditions to development of fungi present in the soil.

For bean (Phaseolus vulgaris L.) seeds, lots submitted to regimes of absence of oxygen for periods of 16 to $48 \mathrm{~h}$, the germination was severely impaired. These lots showed decrease of germination of up to $68 \%$ (Custódio et al., 2002). Thereby, it is possible that for soybean seeds or any other plant species similar results may be obtained, since $\mathrm{O}_{2}$ is essential for respiration and to obtain energy for the seeds can complete the germination process (Carvalho and Nakagawa, 2012).

Other studies have emphasized the efficiency of germination under different water availability as a procedure for the assessment of seed vigor. This procedure showed a high correlation with other tests (Schuab et al., 2007). Furthermore, showed an efficiency similar to accelerated aging test, in assessing the effect of soybean $\mathrm{cv}$ BRS $245 \mathrm{RR}$ at potentials of -0.1 or $-0.3 \mathrm{MPa}$ at $25^{\circ} \mathrm{C}$, or $-0.3 \mathrm{MPa}$ at $30{ }^{\circ} \mathrm{C}$ (Costa et al., 2012).

In function of the expressive variation in the values of the Euclidean distance, among the seed lots for the set of variables considered, it was possible to divide the original set into two groups: I and II (Figure 1) by adopting the threshold distance of 3.9 (Figure 2); and these groups have revealed a fairly meaningful result: the ordering of seed lots in function of cultivar. In group I were concentrated the seed lots belonging to the cultivar M-SOY $7908 \mathrm{RR}$, and in group II the seed lots belonging to cultivar BRS Valiosa RR.

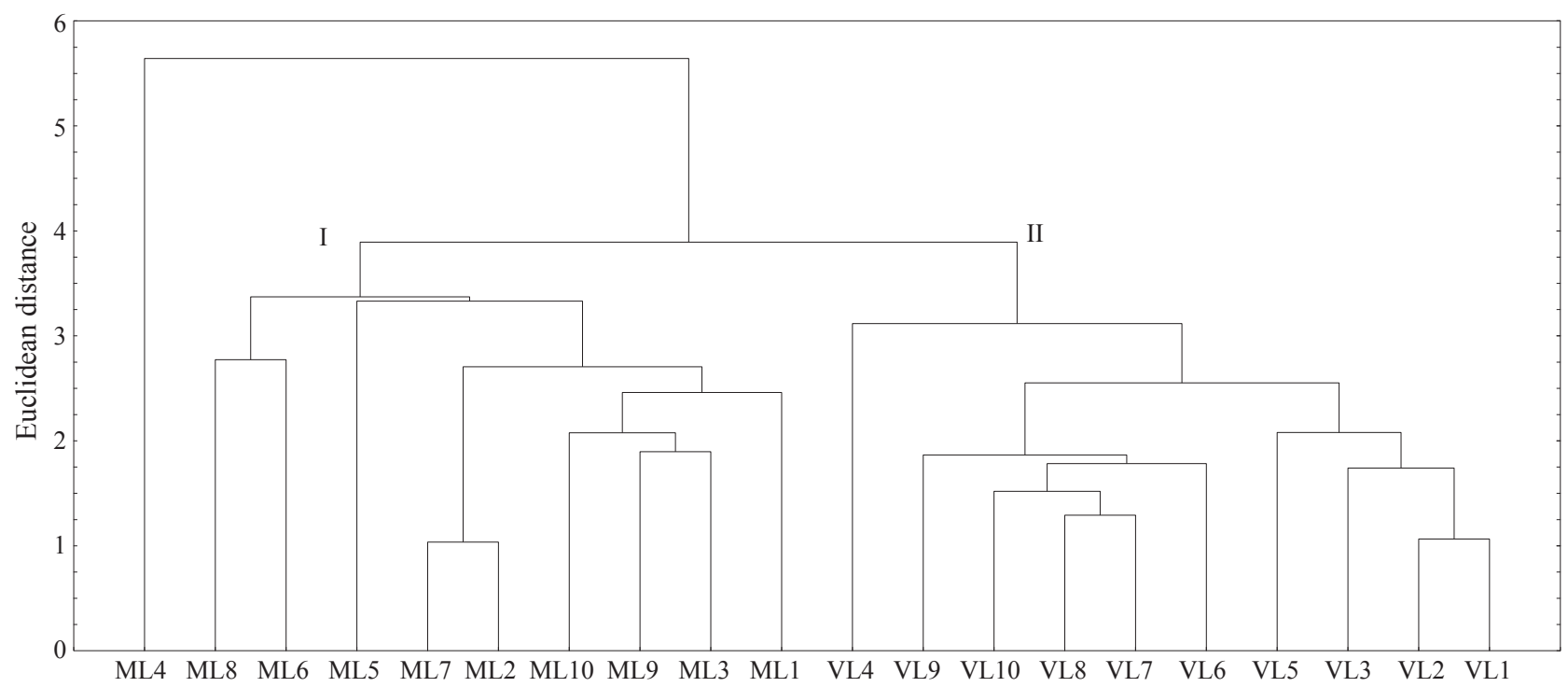

Figure 1. Dendrogram resulting from hierarchical cluster analysis with formation of groups according to germination, accelerated aging, electrical conductivity tests, seedling emergence in the field, and germination under different water availability of soybean cv. BRS Valiosa RR (VL1 to VL10), and cv. M-SOY 7908 RR (ML1 to ML10).

On Figure 3 is shown the biplot graph, resulting from the principal components analysis, showing the correlation of the cluster analysis on the splitting of the seed lots into two distinct groups. The two principal components (PC1 and $\mathrm{PC} 2$ ) were able to hold together $65.9 \%$ (48.7\% by $\mathrm{PC} 1$ and $17.16 \%$ by PC2) of the original variability. 


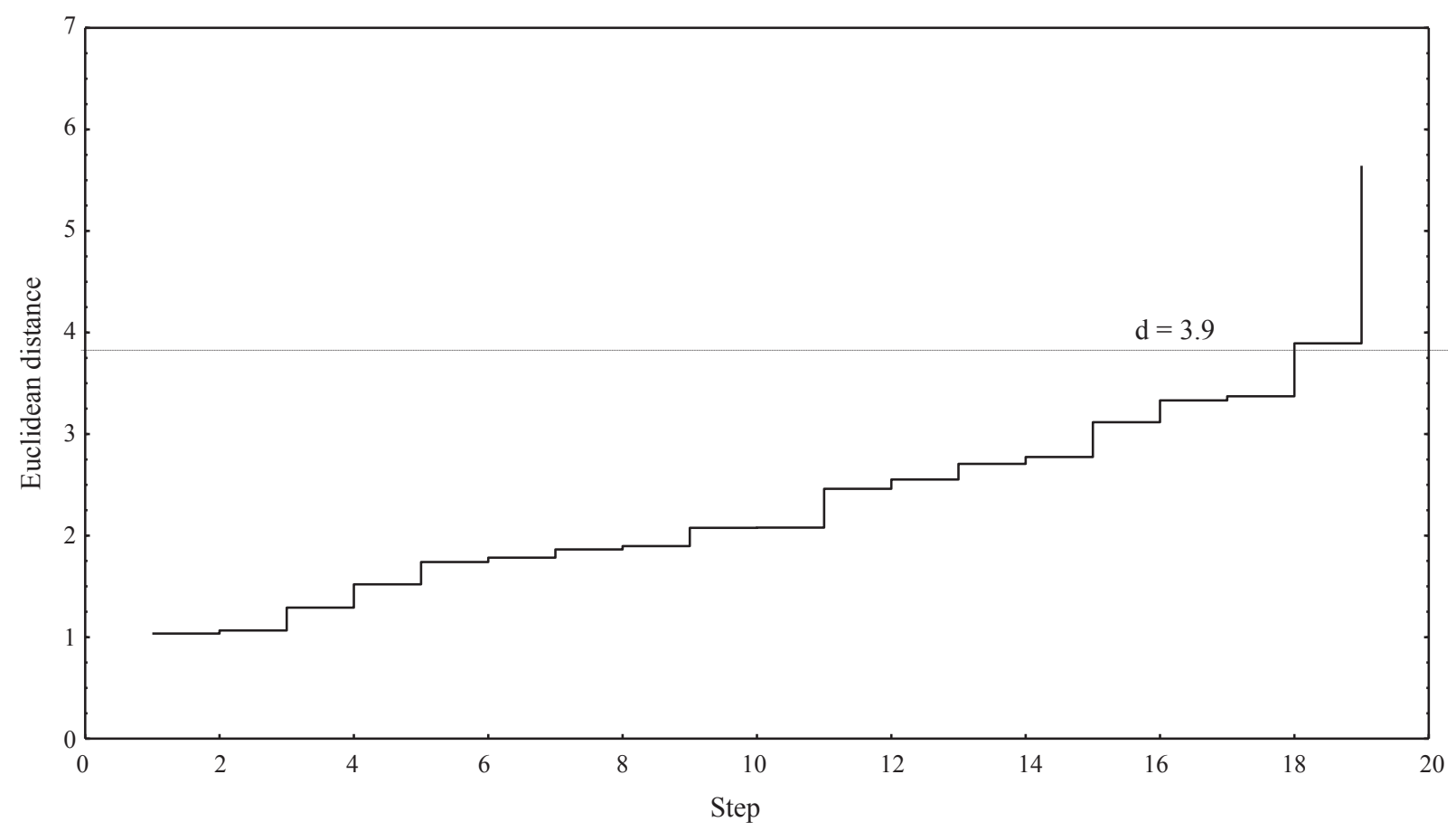

Figure 2. Graphical representation of the large variation of Euclidean distance between the variables considered and that allowed the separation between groups of seed lots.

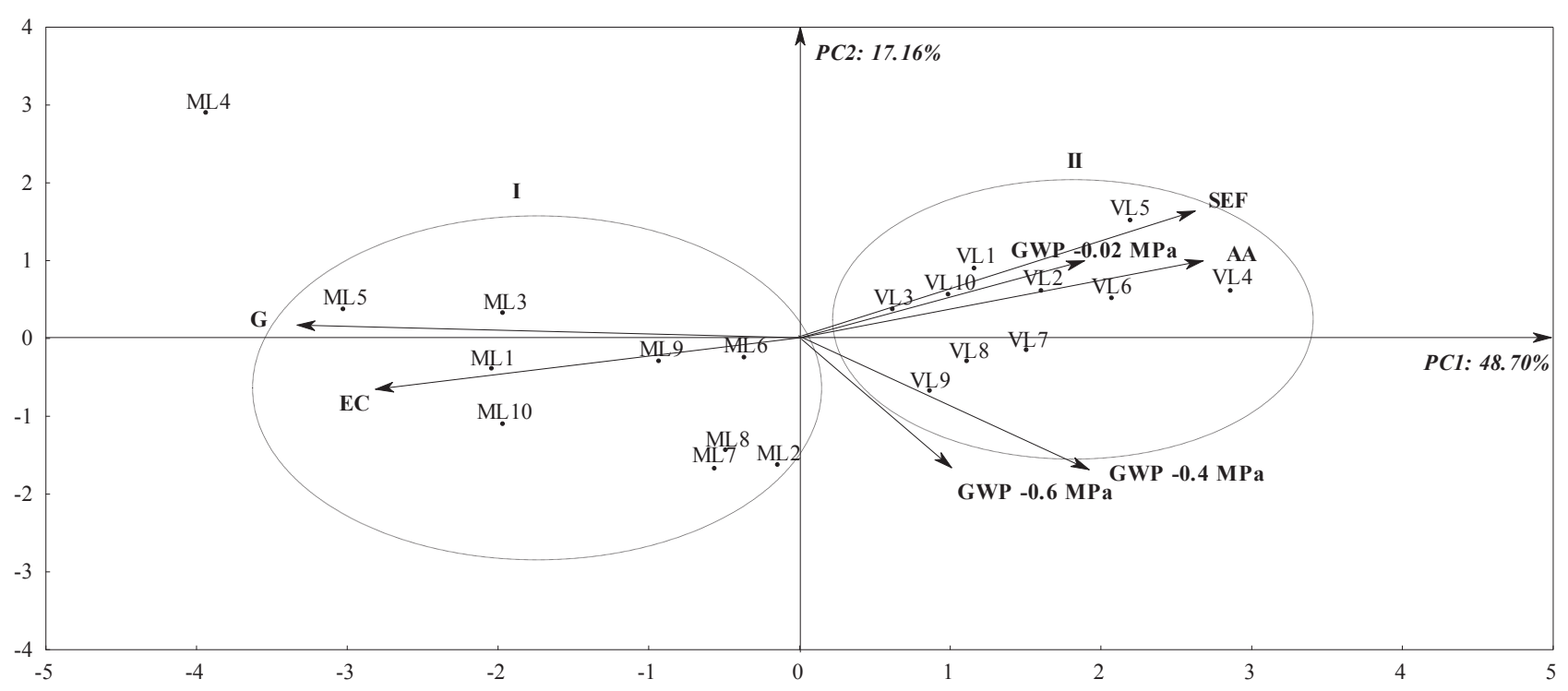

Figure 3. Biplot graph showing the physiological performance of different soybean seed lots of cv. BRS Valiosa RR (VL1 to VL10) and cv. M-SOY 7908 RR (ML1 to ML10). G = germination; EC = electrical conductivity tests; SEF = seedling emergence in the field; AA = accelerated aging; GWP germination under water potential.

The discriminatory power of the variables in each principal component is measured by the correlation between each variable and a principal component. The germination variables (correlation equal to -0.84) and electrical conductivity (correlation equal to -0.84 ) (Table 2) were responsible by discrimination of group I, located the left in the PC1 (negative correlations). Thus, group I was characterized by seed lots with higher potential to originate seedlings under favorable developmental conditions, similar to those conditions used in the standard test of germination. However, 
seeds of those lots presented problems related to integrity of membrane systems, which was evidenced by the electrical conductivity test. Therefore, this may explain the reason why the germination of the seeds of those seed lots were not in agreement to the vigor tests based on water stresses, such as the accelerated aging test, and even the germination of the seeds performed under water stress.

Table 2. Correlation between each principal component and evaluation of the seed physiological performance of the soybean cultivars BRS Valiosa RR and M-SOY 7908 RR.

\begin{tabular}{lrr}
\hline \multicolumn{1}{c}{ Variable } & $\mathrm{PC}^{1}$ & $\mathrm{PC}^{2}$ \\
\hline Germination & -0.84 & -0.02 \\
Accelerated aging & 0.83 & 0.11 \\
Emergence of seedlings in field & 0.81 & 0.27 \\
Electrical conductivity & -0.84 & -0.26 \\
Germination at $-0.6 \mathrm{MPa}$ & 0.30 & -0.83 \\
Germination at $-0.4 \mathrm{MPa}$ & 0.58 & -0.59 \\
Germination at $-0.02 \mathrm{MPa}$ & 0.47 & 0.10 \\
\hline
\end{tabular}

${ }^{1} \mathrm{PC} 1=$ principal component $1 ;{ }^{2} \mathrm{PC} 2=$ principal component 2.

Assessments of seedling emergence in field, accelerated aging and germination under water stress, under potentials of $-0.6,-0.4$ and $-0.02 \mathrm{MPa}$ showed a correlation equal to 0.81 , $0.83,0.30,0.58$ and 0.47 , respectively (Table 2), and were then considered as responsible by the discrimination of group II, located to the right of PC1 (positive correlation) (Figure 3). Thereby, group II is characterized by seed lots that have seeds with greater potential to germinate under adverse conditions, in function of its performance and its good correlation with the vigor tests performed under water stress.

This way, tests based on stresses such as the accelerated aging test might provide accurate information about physiological potential of the seeds, and may also be used as a tool on deciding if seeds are suitable for storing or sowing; even under adverse environmental conditions.

In the second principal component, the seeds germinated under water stress, in the potentials of -0.6 and $-0.4 \mathrm{MPa}$ showed correlation values of -0.83 and -0.59 , respectively and have discriminated the seed lots that tended to bottom of the biplot graph (Figure 3). This indicates that the seeds of these lots have greater ability to germinate under conditions of low water availability. This relationship is not as obvious as those presented for the $\mathrm{PC} 1$; since this component retained most of the information contained in the variables of the experiment. Hence, by retaining only $17.16 \%$ of the total variability of experiment, in relation to the $\mathrm{PC} 1$, the $\mathrm{PC} 2$ has expressed little action in the discrimination of groups.
According to results obtained for germination under the different water availability, the lot L4 (cv. M-SOY 7908 RR) has shown low performance; once it has presented specific characteristics that have not correlated it with the other seed lots; thereby, making that cluster analysis, as well as the principal components analysis, were able of excluding it from the group.

The clustering and the distribution of the seed lots by the principal components analysis have demonstrated the formation of two distinct groups of cultivars; which have been discriminated by genetic patterns and by the good results obtained for physiological performance of the seeds assessed by the tests of germination and vigor.

The multivariate analysis techniques have been employed in areas such as genetics and plant breeding; however the studies with this type of analysis related to the area of seed technology are still scarce in the literature. Therefore, this study is an attempt to introduce multivariate techniques to discriminate large sets of seed lots.

The principal components analysis has already been successfully employed to study variability between the origin of the soybean seed lots and the chemical composition of their seeds (Carrera et al., 2011); to describe the profile of market of wheat seed producing companies (Acosta et al., 2002) and also on identifying a western wheatgrass germplasm [Pascopyrum smithii (Rydb.)] with high production of seeds (Robins et al., 2012).

According to the obtained results, further research become essential for the use and validation of the method. The consideration of all evaluation tests performance potential of seeds to explore and describe the variability of lots proved possible, and that can be used to eliminate the subjectivity of discrimination lots considering variables individually.

\section{Conclusions}

Techniques of multivariate cluster analysis and principal components analysis are efficient tools for discriminating lots of soybean seeds.

Multivariate techniques were able to stratify the seed lots into two distinct groups. Assessments of seedling emergence in the field, accelerated aging, and germination under different water availability were associated to group of the cv. BRS Valiosa RR by the principal component analysis; whereas germination and electrical conductivity were associated to the cv. M-SOY 7908 RR. 


\section{References}

ACOSTA, A.; BARROS, A.C.S.A.; PESKE, S.T. Tipologias e composto mercadológico de empresas de sementes de trigo e soja do Rio Grande do Sul. Revista Brasileira de Sementes, v.24, n.1, p.81-90, 2002.http:// www.scielo.br/scielo.php?script=sci_arttext\&pid=S0101-31222002000 $100012 \& \operatorname{lng}=$ en\&nrm=iso.

ALVES, M.C. Estatística multivariada SAS: Ciagri 23. Piracicaba: ESALQ/ USP, 1999. 111p.

BARBOSA, R.M.; SILVA, C.B.; MEDEIROS, M.A.; CENTURION, M.A.P.C.; VIEIRA, R.D. Electrical conductivity and water content in peanut seeds. Ciência. Rural, v.42, n. 1, 45-51, 2012. http://www.scielo.br/pdf/cr/ v42n1/a0812cr4615.pdf

BRASIL. Ministério da Agricultura, Pecuária e Abastecimento. Regras para análise de sementes. Secretaria de Defesa Agropecuária. MAPA/ACS, Brasília, DF, Brasil. 2009, 395p. http://www.bs.cca.ufsc.br/publicacoes/ regras\%20analise\%20sementes.pdf

CARRERA, C.; MARTÍNEZ, M.J.; DARDANELLI, J.; BALZARINI, M. Environmental variation and correlation of seed components in nontransgenic soybeans: protein, oil, unsaturated fatty acids, tocopherols and isoflavones. Crop Science, v.51, n.1, p.800-809, 2011. https://www.crops.org/ publications/cs/articles/51/2/800.

CARVALHO, N.M.; NAKAGAWA, J. Sementes: ciência, tecnologia e produção. 4.ed. Jaboticabal: FUNEP, 2012. 590p.

CONAGIN, A.; NAGAI, V.; AMBRÓSIO, L.A. Principios de Técnica Experimental e Análise Estatística de Experimentos. Campinas: FUNDAG/ IAC. 2006, v.1. 994p.

COSTA, D.S.; NOVEMBRE, A.D.L.C.; ROCHA, C.R.M. Hydric restriction as vigor assessment method of soybean seeds. Revista Brasileira de Sementes, v.34, p.241-246, 2012. http://www.scielo.br/pdf/rbs/v34n2/08.pdf

CUSTÓDIO, C.C.; MACHADO NETO, N.B.; ITO, H.M.; VIVAN, M.R. Efeito da submersão em água de sementes de feijão na germinação e no vigor. Revista Brasileira de Sementes,v.24, n.1, p.49-54, 2002. http://www. scielo.br/scielo.php?script=sci_arttext\&pid=S0101-31222002000100009 $\& \operatorname{lng}=\mathrm{en} \& \mathrm{nrm}=$ iso.

EMBRAPA. EMPRESA BRASILEIRA DE PESQUISA AGROPECUÁRIA. Manual de métodos de análise de solo. 2.ed. rev. e atual. Rio de Janeiro, 1997. 212p. (Embrapa - CNPS. Documentos, 1). http://www.agencia.cnptia.embrapa. br/Repositorio/Manual+de+Metodos_000fzvhotqk02wx5ok0q43a0ram31wtr.pdf

HAIR, J.F.; ANDERSON, R.E.; TATHAM, R.L.; BLACK, W. Análise multivariada de dados. Porto Alegre: Bookman, 2005. 593p.
JOHNSON, R.A.; WICHERNS, D.W. Applied multivariate statistical analysis. 3.ed. New Jersey: Prentice Hall, 1998. 642p.

KAISER, H.F. The varimax criterion for analytic rotation in factor analysis. Psychometrika, v.23, p.187-200, 1958.

LANDIM, P.M.B. Análise estatística de dados geológicos. 2.ed.São Paulo: UNESP/FEU, 2003. 253p.

MANLY, B.J.F. Métodos estatísticos multivariados: uma introdução. 3.ed. Porto Alegre: Bookman, 2008. 229p.

MARCOS-FILHO, J. Fisiologia de sementes de plantas cultivadas. Piracicaba: FEALQ, 2005. 495p.

MARCOS-FILHO, J.; VIEIRA, R.D. Seed vigor tests: procedures conductivity tests. In: BAALBAKI, R. et al. (Org.). Seed vigor tests handbook. Ithaca, NY, USA: AOSA, 2009. P.186-200.

McDONALD, M.B.; PHANEENDRANATH, B.R. A modified accelerated aging vigor test procedure. Journal of Seed Technology, v.3, p.27-37, 1978.

NAKAGAWA, J. Testes de vigor baseados no desempenho das plântulas. In: KRZYZANOWSKI, F.C.; VIEIRA, R.D.; FRANÇA-NETO, J.B. (Eds.). Vigor de sementes: conceitos e testes. ABRATES: Londrina, 1999. Cap. 2, p.1-24.

ROBINS, J.G.; BHATTARAI, K.; BUSHMAN, B.S.; LARSON, S.R. Relationships among seed quality characteristics in a collection of western wheatgrass germplasms. Euphytica, v.184, n.1, p.131-139, 2012. http://www. springerlink.com/content/htn254u0u9q32434/

SCHUAB, S.R.P.; BRACCINI, A.L.; SCAPIM, C.A.; FRANÇA-NETO, J.B.; MESCHEDE, D.K.; ÁVILA, M.R. Germination test under water stress to evaluate soybean seed vigour. Seed Science and Technology, v.35, n.1, p.187-199, 2007. http://www.ingentaconnect.com/content/ista/ sst/2007/00000035/00000001/art00017

SILVA, J.B.; LAZARINI, E.; SÁ, M.E. Comportamento de sementes de cultivares de soja, submetidos a diferentes períodos de envelhecimento acelerado. Bioscience Journal, v.26, n.5, p.755-762, 2010. http://www.seer. ufu.br/index.php/biosciencejournal/article/view/7187/5265.

SNEATH, P.H.A.; SOKAL, R.R. Numerical taxonomy: the principles and practice of numerical classification. San Francisco: Freeman, 1973. 573p.

STATSOFT, Inc. STATISTICA (data analysis software system), version 7. 2004. www.statsoft.com.

VIEIRA, R.D. Teste de condutividade elétrica. In: VIEIRA, R.D.; CARVALHO, N.M. Testes de vigor em sementes. Jaboticabal: FUNEP, 1994. p.103-132. 